\title{
On the History of the Term "Ethnomusicology"
}

\author{
Bohdan Lukaniuk \\ Mykola Lysenko Lviv National Music Academy \\ Lviv, Ukraine
}

\section{Abstract}

It is generally accepted that the fundamental term "ethnomusicology," as universally accepted in contemporary scholarship, first appeared in 1950 and was invented by the Dutchman Jaap Kunst. In reality, the birthplace of this term is Ukraine where it was proposed and defined in detail in 1928 by Klyment Kvitka. Before World War II the term "ethnomusicology" migrated to Poland, thence to Western Europe and the USA, and from there to all the world.

The date of birth of the term "ethnomusicology" is accepted to be 1950 and the inventor of this term is considered to be the Dutch researcher of musical folklore (1) Jaap Kunst (1891-1960). He used this term in the subheading for his work Musicologica: A study of the nature of ethno-musicology, its problems, methods and representative personalities [Kunst 1950]. The second edition of his book had the title Ethno-musicology [Kunst 1955], albeit hyphenated. And it was only the third edition that introduced the term as it is currently used, namely without a hyphen: Ethnomusicology [Kunst 1959; 1960; 1969]. Kunst justified his invention of the term ethnomusicology by saying that it corresponded to the discipline more accurately than the nineteenth century term "comparative musicology" (2). He also argued that: "The name of our science is, in fact, not quite appropriate; it does not 'compare' any more than any other science. A better name, therefore, is that appearing on the title page of this book: ethno-musicology." [Kunst 1950: 7]

This neologism was immediately picked up in the United States (3) after which it began its triumphal global journey. Earlier terms such as "musical ethnography (ethnology)", "comparative musicology" and "musical folklore studies" were either replaced or forced to obtain a new, mostly secondary, meaning [See for example Goshovskii 1985]. Nowadays the discipline which studies musical folklore is called "musicology" almost everywhere. The majority of institutions and 
periodicals accept the same name and this term for the discipline is generally found in reference works and scholarly literature.

The almost universal acceptance of Kunst's innovation as a major step forward in scholarship should be called into question. Wide acceptance applied only to the term in itself, and not its meaning. The discipline was still amorphously conceived and so Kunst's neologism did not offer anything fundamentally new. Like its predecessors, it also did not provide a definite answer to the main methodological questions: namely the what, why and how of the discipline of musical folklore. In other words, what are this discipline's subject, goals, and methodology? Besides, the supporters of this terminological substitution were unable to elucidate the exact difference between ethnomusicology and musical ethnography, musical folklore studies and comparative musicology. Furthermore, they could not capture the essence of the discipline which usually focuses not only on general comparative musical analysis, but also shares concepts with classical comparative studies such as those used in geology, biology, anatomy, psychology, sociology, ethnography, linguistics, and, to certain extent, literature studies, applying them to the non-written history of mankind.

This study seeks to research the history of the unusual neologism "ethnomusicology," not so much to clarify chronology as to understand its initial meaning, the conditions of its origin, and the reasons that necessitated it. Moreover, it seeks to point out that, despite the prevailing attribution of authorship, one that has already penetrated authoritative encyclopedias and scholarly literature [Hood 1969; Krader 1980; Myers 1992], the originator of the term was not Kunst. He only announced the term at an opportune moment when leading researchers were looking for a new word to replace an old term that had exhausted its usefulness and had even been discredited to certain degree. As often happens with successful beginnings, a messiah has forerunners: the great Dutchman also had his precursors, who had even published the term period to his usage.

Jan Stęszewski may have been one of the first to question whether Kunst coined the word ethnomusicology [Stęszewski 1992]. He proved convincingly that the term was used in the 1930s by Lucjan Kamieński (1885-1964), one of the originators of contemporary Polish folk music scholarship. In his unfinished article, Kamienski pointed out that the folk music recordings in the sound-archive of the Warsaw ethnographic museum (4) could be used during public "ethno-musical lectures." [Stęszewski 1992: 529]. The article was dated 13 December 1934, and 
thus shows that the birthday of the term ethnomusicology, albeit with a hyphen, predates Kunst's usage by a decade and a half. There is an important detail, namely the fact that the author used the term without any elucidation, a fact that implies that this word was already used by his associates and well-known. Moreover, as Jadwiga Sobieska (1909-1995), Kamieński's student and assistant and later a prominent post-war folklorist confirmed, the professor used the term "ethnomusicology" synonymously with "comparative musicology," "musical ethnology," and "folklore studies" in his classes at Poznań University[Stęszewski 1992: 529].

According to Piotr Dahlig, the term ethnomusicology was widely used in Warsaw folklore studies, perhaps under Kamieński's influence [Dahlig 1998: 519-520]. At any rate, in October 1937, one of its representatives, Walerian Batko (1906 - 1947), the music instructor in the Warsaw Institute of Folk Theaters and author of a folk song collection from the Lublin region [Batko 1936] called Filaret Kolessa an "ethno-musicologist" in his review of Volyn' Folk Songs for Mixed Choir (Rivne, 1937) [Dahlig 1998: 268]. This was probably the first appearance of the term in Polish periodical literature and it used the same spelling as in Kamieński's. The term was next published a year and a half later in the journal Teatr ludowy [The Folk Theater] in a response to an amateur collector who was asking where he should turn with his recordings of folk songs. The response, written in February 1939, probably by Batko, stated that folk recordings were "processed by ethnography, ethnology and ethnomusicology [my emphasis - B.L.], new sciences that, for now, have a whole cohort of researchers in this field." [Dahlig 1998: 518] Here, ethnomusicology was printed as a single word (no hyphen) and put on a par with ethnography and ethnology, although perhaps seen as a somewhat different discipline, with the differences unspecified. But what should constitute this difference is a question that remained unanswered in the editorial text.

Both Jan Stęszewski and Piotr Dahlig assume that the creator of the new term could have been Kamieński himself. His language was generally marked by uniqueness of vocabulary and a penchant for neologisms [Stęszewski 1992: 529; Dahlig 1998: 519]. Even if he were really the inventor of the term, still he had he precursors. Earlier, in 1928, this neologism was proposed by another prominent researcher of folk music, one of the founders of Ukrainian school of ethnic music studies, Klyment Kvitka (1880 - 1953). He was not only the first to use the term in print, he also argued for its appropriateness, giving it a clear 
definition and spelling out the essence of folk music studies - their subject matter, objects, goals and research methods.

Perhaps Kvitka's suggestion influenced his Polish colleagues, but neither his nor their innovation made an impression on the world folklore studies community and was not properly appreciated at the time. The main reasons for this are obvious: ethnomusicology, like all liberal arts in Eastern Europe, was isolated from world scholarship and appeared nonexistent. Also important is Kvitka's unfortunate fate, a fate experienced by many scholars of Ukrainian origin and one that doomed his legacy to obscurity.

Because of an incurable illness from his youth (approximately 1896 on), Kvitka was forced to renounce a career as pianist, the career he desired (5). But he had an amateur interest in folk music and devoted his free time, first as a student and later as a lawyer, to the thorough study of available ethnographic literature, occasionally collecting folk songs. In 1908, together with his wife, the Ukrainian poetess Lesia Ukraïnka (Larysa Kosach), he took an active part in the famous joint project of recording dumy, which were then transcribed and published by Kolessa [Kolessa 1969]. In general, during the first twenty years of his not very systematic musical-ethnographical work, he managed to publish only two compilations of folk melodies, two occasional articles, and two reviews of a popular character (6), a meager indication of his creative potential. Capping the amateur period in Kvitka's life was his collection of folk songs recorded from Lesia Ukraïnka (7). Kvitka's high level of scholarship, his fastidious recording, his classification by genre and content, his publication of musical and lexical variants, his analytical textual comments quickly brought him recognition as the producer of classic Ukrainian folk song collections.

The rest of the folk music gathered by Kvitka became a part of his next anthology [Kvitka 1922], which was fundamentally different from the previous one in genre. It was to be a representative collection of folk song tradition from all Ukraine on the pattern of the publications by Ilmari Krohn [Krohn 1893-1933], František Bartoš and Leoš Janáček [Bartos and Janáček 1899-1901], Osyp Rozdolsky and Stanislav Liudkevych [Rozdolsky and Liudkevych 1906-1908], Béla Bartók [Bartók 1924], and others. Due to extremely unfavorable circumstances Kvitka was unable to fully implement his project (8). The concise survey statement in the preface to the collection showed serious changes in Kvitka's outlook: he had gone from a romantic amateur who sought to capture the creativity of the people to a professional researcher, a 
scholar, who "felt like a member of the joint project aimed at contributing new data to scholarship, data that resulted from the study of folk music as one of the phenomena of the process of cultural history" [Kvitka 1971: 33].

At that moment Kvitka consciously decided to study folk music as one of the least researched fields of Ukrainian humanities: "If I had observed that musical folklore was being thoroughly investigated by qualified ethnographers, I would have turned to the study of the visual and plastic arts," he wrote [Quoted in Storozhuk 1998: 12]. In 1920, he became an employee of the All-Ukrainian Academy of Sciences (AUAS), where he organized the first Ukrainian research center for collecting musico-ethnographic materials, both sound recordings and scores [Kvitka 1930: 5-22]. It is indicative that this center's original name "The Office of Comparative Musicology" was quickly changed to "The Office of Musical Ethnography" (9).

Full of enthusiasm, Kvitka developed a program for extensive folk music research [Kvitka 1923]. But it proved impossible to implement this program even partially. Kvitka encountered indifference from the AUAS administration and, despite his efforts to develop the Office and to surround himself with active, knowledgeable colleagues, he continued to be the Office's sole worker. Despite the lack of support and the lack of professional colleagues, which was mitigated only by correspondence with foreign colleagues, Kvitka made giant strides as a researcher. He produced several essays every year that retain, and will probably always retain their significance (10). A prolific scholar, he produced his most important publications on Ukrainian ethnomusicology during the relatively short Kyiv period of his work. He made a significant contribution to the development of ethnomusicological thought and became a leader of Ukrainian scholarship.

The Bolshevik repression in Ukraine that aimed to destroy its scholarly elite and national intelligentsia did not bypass Kvitka. To escape, he followed many other prominent Ukrainian scholars such as Volodymyr Vernadsky, Mykola Zerov and others, and left Kyiv in the summer of 1933 to work as a teacher in the Moscow Conservatory. But the following year the Soviet secret police arrested Kvitka and he was sent to one of the countless Soviet concentration camps. Accidentally released two years later, he returned to Moscow, where he allegedly engaged in scholarly work, lectured on musical folklore at the conservatory and even headed the Office of Folk Music. The facts indicate that, after the trauma he experienced in 1931, Kvitka ceased 
publishing his research. During the two decades that he lived in Moscow he managed to publish only a single article [Kvitka 1941: 123-131] and that under the patronage of Leningrader Evgenii Gippius. In the post-war thaw of the late forties, Kvitka again tried to return to research, as his numerous manuscripts (11), including clean typescripts ready for the printer, attest. But the short thaw was quickly replaced with a new Stalinist freeze and none of Kvitka's manuscripts were published during his lifetime. Only a small fragment of those works was published posthumously (12). One can only guess how much more Kvitka would have contributed to scholarship had the circumstances of his life been normal.

Honored pro forma, mainly for his erudition, Kvitka was ignored or even disregarded to the point of contempt (13). His small scholarly heritage, some three dozen articles published in Ukrainian journals with a limited circulation, was similarly overlooked. A true miniaturist, Kvitka did not try to write a monograph (14) and lived for many years in oblivion. As if anticipating his lot, he wrote in one of the essays:

\begin{abstract}
"For one who is alone in his field or has only a limited number of colleagues and students it is a tragedy of life that reviews of his work, if they even appear, are limited to general phrases that prove that no one has troubled to study the works in detail. The anticipation that the same general phrases will also appear in the obituary, to be followed by total oblivion, is like the spectre of a second death - the death of one's work. Anabiosis (15) is a matter of accident; there may be some who resuscitate one's work or reveal an active interest in it - and then again there may not. When the state of morbidity comes from one's work being completely ignored, that is not so bad; dogmatic recognition is worse."

"One must always stick to that prescription when speaking to students of folk music because that branch has no secure place, either in the community, or in the scholarly enterprise supported by the state. It depends on accident; will individuals appear who are profoundly interested in this field? Do these individuals have a constitution strong enough to undertake this work? Will their life circumstances permit them to become enthusiasts and idealists? Such individuals are not found in every country, or at all times, and the continuation of work in this field is always problematic." [Kvitka 1928: XLVII]
\end{abstract}

Enthusiasts and idealists actively interested in Kvitka's works were found. Attracted by the level of his scholarship they did revive his work. Especially important were the efforts the folklorist-musicologist from Lviv Volodymyr Hoshovs'kyi (1922-1996). In the early 1970s he prepared the majority of Kvitka's works for republication in Russian translation, adding a number of his unpublished manuscripts. He 
provided thorough and thoughtful commentary to every work, giving it its due and revealing its content and significance [Kvitka 1971, 1973]. Anatolii Ivanyts'kyi supplemented Hoshovs'kyi's efforts and expanded the Moscow edition [Kvitka 1985, 1986].

Those collected publications and the commentary to them revealed Kvitka for what he was: a connoisseur of oral-musical culture, a dedicated servant to the cause of its recognition, and also a profound thinker, brilliant innovator, well ahead of his era, who expressed ideas that would become "epoch-making discoveries" only after his death. These ideas include Kvitka's criticism of the concept of the historical primacy of the pentatonic in the development of modal thinking. Kvitka voiced this idea some thirty years before the "revolutionary" breakthrough by Walter Wiora and others [Wiora 195: 185-208; Kvitka 1971, 1: 274-278, 308-311]. Also important are Kvitka's studies of folk music in context, an approach that came to scholarly research only in the final third of the last century as a result of the "musical-anthropological" revelations of Alan Merriam [Merriam 1964; Kvitka 1971, 2: 253, 277278, 325-326]. Kvitka's structural typology of folkloric plots, it turns out, was later "invented" by philologically oriented folklorists for the classification of tales [Kvitka 1971, 2:194-196]. His methodology of algorithmic modeling melo-typology, his statistical data interpretation of melo-geography [Kvitka 1971, 1: 59-60, 1971, 2: 193], textological aligning of musical-ethnographic sources [Kvitka 1971, 2: 38-39], and many other innovations remain unprecedented in folk music scholarship.

Kvitka worked much and purposefully on musicological terminology, its refinement and development, and introduced many completely new concepts and terms (16). It is he who suggested the neologism "ethno-musicology" (with the same hyphenated spelling as used by Kamieński, Batko and Kunst). He proposed this neologism in an article that examined the historical value of the first printed collection of Ukrainian folk melodies (17) [Kvitka 1928: 119-144]. For some reason this article was not reprinted by either Hoshovs'kyi or A. Ivanyts'kyi. Its original, of course, was inaccessible due to the ban on the literature of the so-called "Ukrainization" of 1920 - 1929 period. This literature was available exclusively in special library collections which could be used only after having receiving permission from Soviet government authorities. This probably explains why this work by Kvitka went unnoticed by scholars and remained little known not just by the general public, but even by most experts. This has been a loss to scholarship because the work contains valuable considerations of general 
methodological significance as well as a detailed review of theoretical issues concerning the scholarly disciplines and the terminology that deal with folk music.

We should mention that 1928 was not the first time that Kvitka concerned himself with terminological issues. In an article of purely propaedeutical orientation [Kvitka 1925: 8-27] published several years earlier, he opposed the replacement of the traditional term "musical ethnography" with the more fashionable "comparative musicology" (18). Kvitka stressed that "in principle, both terms deal with ways of positing the problem rather than with the subject of analysis." "Musical ethnography or comparative musicology actually involve the music of less developed or non-European peoples and, within the European cultural world, it addresses only the music that is transmitted without scores and the benefit of the written musical text." (19) The difference between these two disciplines is rather illusory, he continued, because they both seek to solve historical issues. We might note here that, in those days, ethnography was considered to a historical science. As summed up by Kvitka, in view of the unity of both the subject and the purpose of analysis, "the parallel existence of these two sciences is unjustified." "[...] By excluding what might belong in the domain of comparative musicology, musical ethnography would cease to be a science; but if it is to remain a field of study, it can exist only as comparative and evolutionary scholarship" [Kvitka 1925: 9]. Kvitka asserted that the two terms should be regarded as virtually synonymous and that preference for one or the other be given only according to national traditions. He personally preferred the term "musical ethnography" (20) and put his preferences into practice by changing the name of the institution he had organized from the "Office of Comparative Musicology" to the "Office of Musical Ethnography" (See note 9).

Kvitka returned to the problem of terminology several years later in his article about M. Maksymovych's collection. Here he tried to clarify his understanding of basic terms as they reflect the fundamental methodological issues of the field of oral music. As he wrote, the "name 'musical ethnography' is established in our country and is usually used superficially and too generously." "Strict conditions should be used to define the direction of investigation and it should be clear that it is an area of ethnography." It "should be characterized by the direct observation of facts and phenomena, their all encompassing comprehensive description, and generalization on the basis of precisely 
this kind of work". It was Kvitka's conviction that "multiyear stationary ethno-musicographical [my emphasis - BL] work in the village could bring much that is missing to anthropological study." In other words, thorough and comprehensive "observation of musical life" [Kvitka 1928: LXIII], would aid in understanding the processes of song creation, the migration and transformation of song, the interrelation of the individual and collective in folk art. Fieldwork would help us see the relation between professional and non-professional folk music, especially in connection with folk instrumental dilettantism. It would help develop proper folk music terminology and help us understand musicality in a particular place. Field observation would reveal, "those aspects of melody and rhythm that are the achievement of the folk as a group and those aspects that should be attributed to the virtuosity of gifted individuals". It would reveal how below-average singers simplify or deviate from the norm [Kvitka 1928: LXIII] (21). At the same time "one can state that, at this time, we still lack a musical ethnography in the strict sense." emphasized Kvitka. [Kvitka 1928: LXIII]

Kvitka also asserted that the scholarly field which studies folk music should be seen not only as a part of ethnography, but also as a branch of musicology. This is "analogous to other disciplines which the study other types of folk art and are both branches of ethnography and branches of the appropriate art disciplines. [However,] we cannot conclude that this approach requires the introduction of the term 'ethnomusicology' [emphasis supplied - B.L.] to supplement the term 'musical ethnography' already in existence. In the realm of ethno-musicology one can envision the core of the discipline and the analysis of the melodies themselves" [Kvitka 1928: LXIII]. Kvitka did not develop this last statement any further, apparently having in mind the classic analysis of musical works (22) outside of their actual existence, which developed in the nineteenth century and is still taught in all Ukrainian schools [See for example Marx 1839; Riemann 1889; Sposobin 1947; Mazel' 1960; Liudkevych 1921; Iakubiak 1999].

Thus, in Kvitka's system, music, taken as a whole should be divided into two fundamentally different research domains. One of them is the European world; it is music that exits under the constant control of the written musical text (i.e. "written music") (23). The other is music devoid of such control, or "oral music," what can also be called "folk" or "ethnic music" and abbreviated "ethnomusic" (24). Written music is studied by the discipline commonly known as "musicology" (Ukrainian - muzykoznavastvo). Oral music should be subdivided into branched 
lines, depending on the emphasis of the study on either the musical works themselves or on the context of their performance. The first branch, which is close to musicology, should accordingly be called "ethno-musicology", while the second, should be named "musical ethnography" (or perhaps "ethno-musicography"). Here the methodologically of ethnography should apply. Kvitka's train of thought can be presented graphically in this conceptual-terminological system:

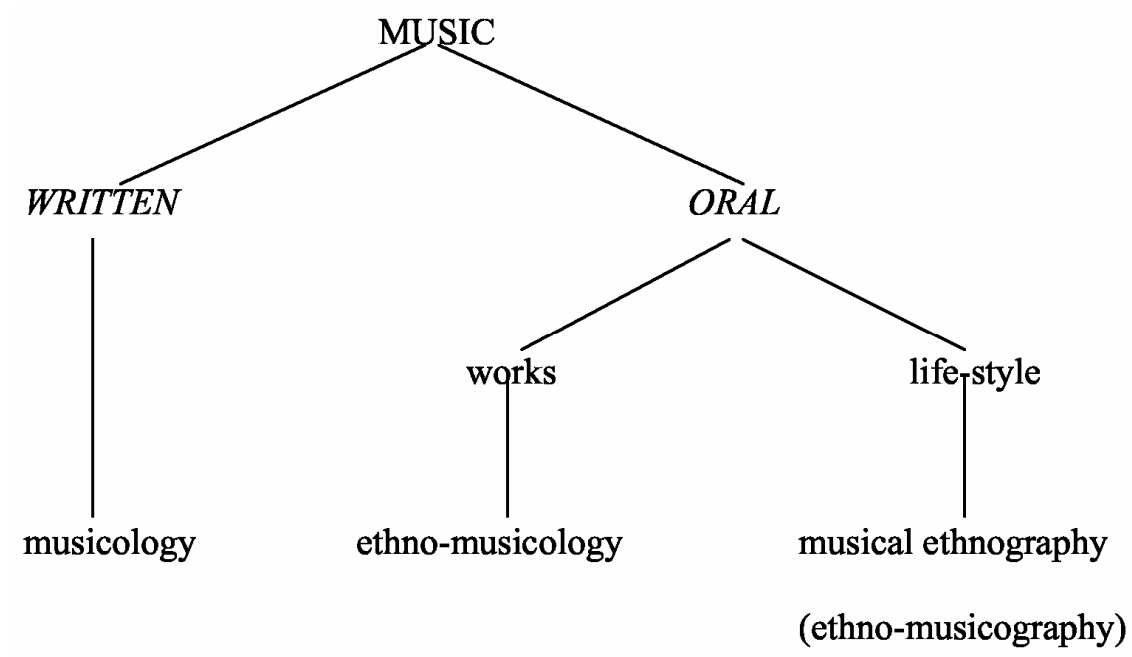

Such was the reasoning that led Kvitka to the invention of term "ethno-musicology." This reasoning is consistent with contemporary views on the main internal divisions in the study of oral music. Here the objects of study are differentiated into two sub-disciplines: one of them dealing with music per se (musical works, their lyrics - sound or printed music), and other dealing with musical life as it manifests itself in musical culture and its functioning in the community. [Nettl, 1992: 266277; Czekanowska 1987; Żerańska-Kominek 1995]. In those distant 1920 s, no one except Kvitka raised the issue in these terms. Although the problem did come up in studies of oral music, works of oral music, texts in musical notation, remained the main object of study, along with, as Liudkevych put it, the circumstances under which those works were performed [Liudkevych 1906, 1908: XI]. Special interest in musical life appeared only with the establishment of the sociological and functional approached in ethnography (25). From the middle of the twentieth century onward, the latter deliberately studied ethnomusic, thus 
inaugurating a new discipline, best known from Alan Hart Merriam's Musical Anthropology [Merriam 1964]. It was this work that lead to the proliferation of the term and its recognition.

Generally, the term "anthropology" has three meanings. In Ukraine it most often means the biological science that studies the origin and evolution of man, differences in physiology, origin of human races, and so on. Less often it is used to define the philosophical study of the essence of man, particularly in terms of his existence. On the other hand, in English-speaking countries, mainly in the United States, the term anthropology usually refers to analysis of the culture of different peoples, especially primitive ones. It is usually treated as a synonym for ethnography, in the sense of ethnology or the study of peoples. Contemporary musical anthropology generally corresponds to "musical ethnography" ("ethno-musicography") in Kvitka's conceptual and terminological system. As can be seen, Kvitka's prediction came true: thirty years after his research on musical life finally became a separate discipline, although not in his homeland, but overseas.

Kvitka's musical ethnography is not quite the same as A. P. Merriam's musical anthropology. Dissimilar concepts stand behind these different terms the sub-disciplines to which they are applied. Having a common object, they study different subjects, specifically different aspects or viewpoints or, to use Kvitka's expression, different ways of posing the problem. Ethnography and its musical branch are historical sciences that try to understand music in cultural context from a diachronic perspective. Anthropology, which is closer to sociology than to ethnography, studies the same object only from a synchronic point of view, avoiding the historical perspective.

Today, musical anthropology has become a leading discipline in the study of oral music. As a result, many enthusiastically share the views of its founder, that "ethnomusicology ... is the study of music within culture" [Merriam 1964]. Thus, as once was the case with "comparative musicology," the same error of identifying of parts with the whole is made and musical anthropology is seen as as a separate sub-discipline of oral music in all its diverse manifestations. At the same time, the term earlier proposed by Kvitka has developed in the opposite direction. After all, according to Merriam, "musical anthropology" is an antonym of "musical ethnography" or "ethno-musicography," but their synonym. As a result, another area of research on oral music for which Kvitka invented neologism, again remained untimely without a term to label it. 
Such incidents can be seen as the negligent attitude toward terminology that has come to be a hallmark of the humanities. Scholars in the humanities, it seems, have become accustomed to employing wellknown terms at their own discretion and without troubling to look for the term's initial meaning. Therefore, different authors, and sometimes even the same author, can interpret the same concept differently. Sometimes the same term can be used in opposite meanings, as is the case with the musicological terms "intonation," "mode," and others the have no meaning outside a certain context. Scholars in the humanities do not study terminology. Moreover, for most of them, the existence of strict rules of origination and use of terms seems exotic. Hence, in works in art history, literary studies and similar disciplines, terminology use as strictly as in the exact sciences. Rather, it represents spontaneously developed terminological-like wording.

In the case of the term "ethnomusicology", the problem is rooted in the very nature of oral music scholarship, which has been and remains a heterogeneous discipline that deals with many disparate spheres of human activity beginning from art and ethnography and ending with psychology and acoustics. Each sphere pursues its own interests and uses appropriate methods, considering them to be the only correct ones. Their separate approaches have not been subordinated beneath a common denominator and universal theoretical concept signified by a single term. If, however, the study of oral music were conceptualized, not as branches of related disciplines, but as components of an independent science with its own range of general methodological questions, with its own distinct object, subjects, aims and means of attaining them then one would be able to avoid the endless substitution of one partially useful term for another.

There are various reasons why it is hardly possible to return to Kvitka's original intentions. One of these reasons is that, in his conceptual system, "ethno-musicology" refers not to all scholarship devoted to oral music, but to a subdivision of this area of work. The issue of subdivisions versus broad terms bothered Kvitka less than the need for distinguish the new ethno-musicographical aspect of research from the existing ethno-musicological. Thus the problem of a unifying term was not resolved, though the word combination ethnomusicology certainly fits this role better than the expression comparative musicology.

It was Kvitka's radical approach that lead to the appearance of this neologism, though it is not impossible that the term was actually invented independently in three different countries over a twenty year 
period, first in 1928 by Kvitka in Ukraine, then in the 1930 Kamieński in Poland, and finally by Kunst in the Netherlands in 1950. There is likely a certain historical connectedness between these events. For the time being, there is no direct evidence, but it is worth positing that the new word combination, proposed by the Ukrainian scholar, traveled through Poland and then reached Western Europe and the United States.

Could the term "ethno-musicology" move from Ukraine to Poland? It would be difficult to imagine that Kamieński or Batko could have borrowed the term directly from Kvitka's article. Perhaps Kyivan academic periodicals were still able to reach Poland at the end of the 1920s. If so, historians, ethnographers, linguists and other specialists considered it their professional duty to examine periodicals in their disciplines would have been exposed to them. All three of the most prominent Polish folk music researchers of the inter-war period Kamieński, Pulikovski, and Chybiński earned their credentials in German universities and were oriented to the Berlin school of comparative musicology. They were not much interested in the academic work of their Eastern European colleagues. Except for Kolessa and Lin'ova, scholars from Eastern Europe were almost unknown. Furthermore, Kvitka was virtually unknown at that time, and even remains so even today. His name is completely missing in the collections of works by Jadwiga and Marian Sobiescy [Sobiescy 1973], Chybiński [Chybiński 1961], Bielawski [Bielawski 1999], and even in the world history of ethnomusicology, recently published at the University of Warsaw [Żerańska-Kominek 1995] (26). And this happened despite the fact that Kvitka's survey of pentatonic of the Slavic peoples, one of the major systems of Polish folk music, was published in Krakow [Kvitka 1930: 196-200].

The term could come to Poland through Kvitka's personal relationship with some of the three above-mentioned leaders of Polish musicology. It is doubtful whether he knew either Kamieński or Pulikovski (27). When they began to organize phonogram-archives in Poznań and Warsaw, an undertaking in which Kvitka was greatly interested, the Iron Curtain fell on the western border of Soviet Ukraine and any private contacts across the border became unthinkable. Hence, we can exclude both prominent representatives from Poznan and Warsaw from Kvitka's direct contacts. Nevertheless, the probability of influence should not be discharged altogether, and we could presuppose that, among people in Kvitka's milieu, some intermediate connection might be found. 
This link could be Kolessa, who lived in Lviv, then part of Poland, and who was Kvitka's friend. But again, it is unlikely that Kolessa could have transmitted Kvitka's idea for he does not mention this concept in his writings (28). Even if Kvitka's idea had attracted Kolessa's attention, he would not have shared it with his Polish colleagues because it was time when Poles and Ukrainians did not develop close relations, a fact that greatly surprised Kvitka. In his letter to Kolessa he wrote:

Further to your words that you are working alone in Lviv, allow me a question: Does Chybiński work in the conservatory, and are national relations even between persons of scholarship so strained that scientific discourse is impossible? Although there is struggle going on in Kyiv, it is not so acute that it would be unpleasant for specialists to consult one another, and if there were Chybińskis among the Russians in Kyiv, I would be much happier. (29)

Kvitka's proposition could have been picked up only by one scholar, the head of the Institute of Musicology at Lviv University Chybiński (1880 - 1952) who, among his diverse activities, paid much attention to folk music [Chybiński 1961]. Kvitka treated Chybiński with respect, referred to his work in his articles, and reviewed his book on folk musical instruments of Podhale [Kvitka and Chybiński 1924]. More important, he was in occasional correspondence with Chybiński and sent him reprints of his works (30). Whether Kvitka's article about Maksymovych's collection was among them is unknown. All that remains is only one fascicle of Kvitka's works with his dedication to Chybiński (31). It does not contain this article (32). In addition to the fascicle, the offprint of one review has been preserved. [Kvitka 1925: 239-250] The rest was lost because it is unlikely that Kvitka would have stopped mailing offprints of his works to Kolessa, one of his best Lviv contacts. Kolessa would have been receiving material from Kivtka regularly until 1931. (33)

If Chybiński had somehow become acquainted with Kvitka's article, then he would have noticed the originality of his idea and shared it with his Polish colleagues. He communicated with them frequently, especially the editor of Kwartalnik muzyczny [Musical quarterly]. Through him the neologism could have reached scholars in Poznań and Warsaw and established itself first in oral use. From oral use it could have penetrated academic periodicals. Batko printed the term. He was a propagandist rather than a scholar and could afford to use freely the terminology of couloirs slang expressions. The innovation did not appear in the strictly academic texts of the late 1930s written by Chybiński, Pulikowski, and 
Kamieński. The distinctive Kvitka hyphenated spelling was quickly replaced by the unhyphenated single word in the works of Batko, and Kunst and others. This may well be not a simple coincidence but an indication of oral use. Chybiński might have copied the hyphenated spelling in a letter to some of his Warsaw and Poznań addressees but, without proper definition, it was seen as yet another synonym and Kvitka's special meaning remained unknown. Only oral circulation gave the term currency, albeit in a somewhat new meaning because Kvitka's call to study oral music in situ would have come as a surprise to Polish musicologists.

Eventually the term became familiar and was brought by a scholar from Warsaw or Poznań to the West. We can assume that this scholar was Mieczyslaw Koliński (1901-1981), a native of Warsaw. In 19261933, he was an assistant to the head of the Berlin School of Comparative Musicology Erich Moritz von Hornbostel (34). Later Koliński lived in Bohemia and Belgium, where he participated in research on the ethnomusic of non-European nations. He likely had contacts with his Polish counterparts (35), as well as with Kunst, who worked at the Amsterdam Institute of the Tropics from 1936. Koliński published a number of Kunst's articles posthumously. Kunst moved to the United States in 1951 and became a promoter of the new term [Koliński 1957, 1959], even initiating a move to rename the Society of Comparative Musicology to the Society of Ethnomusicology (See note 1). A purely hypothetical chain of transmission of the term ethnomusicology would be: Kvitka $\Rightarrow$ A. Chybiński $\Rightarrow$ L. Kamieński / W. Batko $\Rightarrow$ M. Koliński $\Rightarrow$ J. Kunst, in other words: Ukraine $\Rightarrow$ Halychyna $\Rightarrow$ Poland $\Rightarrow$ Netherlands $\Rightarrow$ USA. It is the author's home that documents supporting his suppositions will eventually be found. In the meantime, it suffices to state that the term "ethnomusicology" (with the hyphenated spelling "ethno-musicology") and the definition it has today was proposed for the first time in 1928 by Klyment Kvitka.

Kvitka himself tried to use his own term. In the concluding lines of the critical analysis of theory of primary of pentatonic in the evolution of musical thinking, written in 1928 , he wrote:

self-control is most difficult when it comes to dividing time and energy between different and, at the same time, inseparable aspects of scientific work. As it applies to the ethno-musicologist [italics - B.L.] there is a need to balance the expenditure of time between the need to expand general scientific and philosophical horizons and the need to expand knowledge of the field of musicology. Furthermore, one must balance work within the bounds of the chosen academic discipline with the need to expand general musicological

FOLKLORICA 2010, Vol. XV 
erudition and enlarge ethno-musicological knowledge [italics - B.L.]. Conflicts also exist between comparative ethnological and cultural-historical studies on the one hand and the more detailed comprehensive study of the ethno-geographic field on the other. A third principle division is between deepening the theoretical base of knowledge and expanding its empirical base. Finally there is the conflict between work at one's desk and fieldwork. [Kvitka 1928: 82-83].

Later in the same document we read: "Let fieldworkers work directly under the supervision of a theoretician and according to his instructions. This happens infrequently in ethno-musicology [italics B.L.]" Unfortunately such opportunities were few for Kvitka. As noted above, after 1930 he virtually withdrew from contributing to scholarship. Jan Stęszewski, writing about the history of the term "ethnomusicology," appealed to the academic community, asking that "in new music dictionaries, encyclopedias and instruction manuals the name of Lucjan Kamieński and the date - 1934 not be forgotten" [Stęszewski 1992: 529]. It only remains to add our plea to these words and ask that we also remember the name of Klyment Kvitka and the date 1928.

\section{NOTES}

1 Here and further, the term "musical folklore", "folk (musical) art", "folk music", "ethnomusic", "oral music" and "ethnomusicology", "musical ethnography", "musical folklore studies" are used as synonyms.

2 The term "vergleichende Musikwissenschaft" (Fr. "musicologie comparée", Eng. "comparative musicology", Rus. "сравнительное музыкознание") was proposed by Guido Adler (1855 - 1941) in his programmatic article in the first issue of the musicological journal, edited by him: Adler:14.

3 In late 1953, the journal entitled Ethno-Musicology Newsletters, and in 1955 the term "ethnomusicology" was announced as official, and the Society for Comparative Musicology, founded in 1930, was renamed Society for Ethnomusicology and began to publish the journal Ethnomusicology in 1956.

4 That archive was organized in 1935 by the prominent Polish musicologist of the interwar period Julian Pulikowski (1908 - 1944). About it see: Piotr Dahlig 1993: 119-156, or his 1998: 517-628.

5 Kvitka studied piano as a scholarship recipient of the Musical College of the Kyiv chapter of the Imperial Musical Association.

6 See the list of the published works in Kvitka 1973: 2: 376, №№ $1-5,7$.

FOLKLORICA 2010, Vol. XV 
7 Ukraïnka, Lesia 1917/1918.

8 Kvitka's letter to F. Kolessa from 30 July 1922 in Zales'ka and Ivanyts'kyi: 324-325.

9 In his last known letter to F. Kolessa from 14 July 1931 in Zales'ka and Ivanyts'kyi : 414. Kvitka styled himself as Head of "The Office of Comparative Musicology of the AUAS" (the fact that was even noticed by F. Kolessa, who underlined the words "comparative musicology"), although in all previous letters and in Kvitka's last article from the Kyiv period, "The Office of Musical Ethnography of the AllUkrainian Academy of Sciences" appears everywhere under the name "The Office of Musical Ethnography of the AUAS." Is it possible to assume that it was merely a slip, or did such a change hide a deeper meaning?

10 See the list of Kvitka works in the note 23. In 1923 №№ 10-12, in 1924 - №№ 14-15, in 1925 - №№ 19, 22, 24, in 1926 - №№ 27, 3031, in 1927 - №№ 32-33, in 1928 - №№ 35-37, 39, in 1929 - №№ 41, 43, in 1930 - № 45, 48.

11 See: Kvitka 1971, 2: 381-384.

12 See: "Посмертные издания", Kvitka 1971, 2: 379-380, also we should add: Kvitka 1956: 160-193; also twelve works are in the editions: Kvitka 1985, 1986, and Kvitka 2001.

13 An example of that can be at least some passages in the memoirs of the famous Soviet folklorist Lev Kulakovsky, who once had the opportunity to hear Kvitka's lectures on comparative musicology in the M. Lysenko Higher Music and Drama Institute in Kyiv. Kulakovskii: 3336.

14 One in his letter to F. Kolessa from 4 September 1928 (2 verso) Kvitka confessed that "he is unable to create a big work" Zales'ka and Ivanyts'kyi: 382.

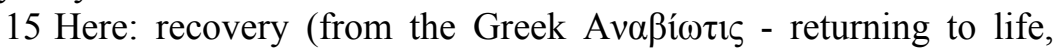
revival).

16 Kvitka 1971/1973, 1: 285 (“ангемітоніка"); 2: 67 (“етнофонія”), 157 (“межиспів”) еtс.

17 The article was written between 22 July and 4 September 1928 , as can be seen from the correspondence of Kvitka and F. Kolessa. See 22 July 1928 (leaf 3 recto) and 4 September 1928 (leaf 2 verso). Zales'ka and Ivanyts'kyi: $380,382$.

18 We should notice that in 1930 the Society for Comparative Musicology was founded in the USA (cf. fn. 7). 
19 Kvitka 1925 a: 8-9 (p. 4 in Russian translation). It is worthwhile to draw attention to the fact that Kvitka gave an unequivocal definition of the subject of study of so-called folk (traditional) music long before it became urgent fifty years ago, moreover, it usually coincides with the definitions that are currently used in classical western ethnomusicology (Merriam, 1977: 201-204. Earlier in the foreword to his second collection, Kvitka declared that the same broad understanding of the concept, signifying that "... folk song is not exclusively a peasant song, but any massively popular song in some segments of society without scores and without the constant control of a fixed printed verbal and musical text." (Kvitka 1922: IX), whereas, B. Bartók, F. Kolessa, and others categorically identified with folk music with peasant music. Bartók 1966: 11-12; Kolessa 1938: 3.

$20 \mathrm{He}$ argued: "If the question relates to whether Ukrainians should use the traditional title "musical ethnography" or change it, the more serious reason to change would be adapting the recent, but stronger tradition of German scholarship, as expressed in the studies of highly regarded scholars" (Stumpf, A. Hornbostel, R. Lach, G. Schönemann and others. - B.L.) and adopt the term "comparative musicology" (ibid.). As can be seen, such an argument was crucial to Kvitka, when he was choosing a name for the Office, but later this became less convincing.

21 In his other article Kvitka formulated the goals of musical ethnography: “... Musical ethnography is not only the recording of melodies; to embrace the whole complexity of its tasks one must make direct observations, talk with the villagers, query them about many things, determine their attitude towards various form of music and songs, study the different preferences of different generations, various professional groups, write down folk music terminology, utterances that express folk attitudes toward music, evaluation of songs and instrumental pieces, etc." Kvitka 1929, 11: 3.

22 Naturally, as it is amended by the oral nature of the subject.

23 Other term used in the scholarship is "artificial music" (From Latin. arte + facio - I make artificially).

24 The term "natural music," as opposed to "artificial," is practically unused.

25 In greater detail cf: Tokarev: Chapters 8-9; Czekanowska. 1983: $21-24$

26 Kvitka is mentioned several times in works by Czekanowska 1983: 43, 44; 1972: 29; 200: 289, and in the work of her student Piotr Dahlig, 1998: 537. 
27 In 1929 Kvitka wrote: “Within the boundaries of today's Polish state the work of musical ethnography is conducted by Drs. Foliaret Kolessa and Adolf Chybiński." Kvitka 1929a 8: 234).

28 Kvitka's typed article on M. Maksymovych's collection now is in F. Kolessa's private library. Mel'nyk-Hnatyshyn: 28, № 249.

29 Zales'ka and Ivanyts'kyi: 330 (letter of 31 July 1923. - leaf 2 verso). We should admit that Chybiński valued highly F. Kolessa's academic work and research (Chybiński 1910, 16: 168-173), but he did not offer him to work at the Musicology Institute of Lviv University. As it is known, the letters of such Polish researchers as A.Chybiński, Z. Jachimiecki, K. Klimaszewska, K. Moshyński, and A. Fischer could be in F. Kolessa's archives.

30 In the second half of 1923 (letter from 31 July 1923), Kvitka wrote: "Chybiński is of great interest to me, especially should I be sending him my works." (Zales'ka and Ivanyts'kyi: 330). From the postscript in the other letter (3 April 1926) we learn that Kvitka had sent A. Chybiński three letters, but did not receive his response to the last one. (Zales'ka and Ivanyts'kyi: 353 ).

31 Having received from Kvitka offprints of his works, A. Chybiński turned them over to the Musicology Institute Library at Lviv University.

32 The fascicle includes the following works by Kvitka: 1925c, 1923, 1926b, and 1924. Now, it is housed in the NDLME [State Research Laboratory of Musical Ethnography?] Reference Library in the M. Lysenko Lviv State Musical Academy.

33 At the end of his letter (14 July 1931), Kvitka informs F. Kolessa that he mails him an issue of the magazine Pobut that includes detailed information about the work of the Office for the years 1921-1930. Zales'ka and Ivanyts'kyi: 414. This concerns the work: Kvitka 1930.

34 About the connections of L. Kamieński and Hornbostel see: Dahlig 2000a and 2000b: 118-122.

35 The name of M. Koliński is mentioned in the letter of $\mathrm{L}$. Kamieński to Hornbostel of 14 October 1930 (Dahlig 2000b). We can state that Kvitka referred on the publication of the dissertation of M. Koliński 1930 in his manuscript "Пентатоніка у вірменській народній музиці", which can be dated tentatively 1932-1933. (cf.: Kvitka 2001: 39). 


\section{BIBLIOGRAPHY}

Adler, Guido. 1885. "Umfang, Methode und Ziel der Musikwissenschaft." Vierteljahresschrift für Musikwissenschaft 1.

Bartók, Béla. 1966. Барток, Бела. Народная музыка Венгрии и соседних народов [Folk music in Hungary and neighbouring countries]. Москва: Музыка 11-12.

Bartoš, František and Leoš Janáček. 1899-1901. Národní písně moravské $v$ nově nasbirané [Folk songs from Moravia from new collection]. Praha, vol. 1-2. Česká akadmie cisaře Františka Josefa pro vědy, slovesnost a umění.

Batko, Walerian. 1936. "Lubelska pieśń ludowa." [Folk songs in Lubelsk] Pieśń w szkole 7: 134-142.

Bielawski, Ludwik. 1999. Tradycje ludowe w kulturze muzycznej [Folk traditions in musical culture]. Warszawa: Instytut Sztuki Polskiej Akademii Nauk.

Chybiński, Adolf. 1910. "Etnografia muzyczna na III międzynarodowym kongresie muzycznym w Wiedniu (25-29 V 1909)" [Musical ethnography at the III international musical congress in Wiednia]. Lud 16: 168-173.

Chybiński, Adolf. 1961. O polskiej muzyce ludowej: Wybór prac etnograficznych. [Of Polish folk music: collection of ethnographic articles]. L. Bielawski (red.). Kraków: Polskie Wydawnictwo Muzyczne.

Czekanowska, Anna. 1972. Ludowe melodie waskiego zakresu w krajach stowiańskich. [Folk melodies of narrow ranges in Slavic countries] Kraków: Polskie Wydawnictwo Muzyczne.

Czekanowska, Anna. 1983. Чекановска, Анна. Музыкальная этнография: Методология и методика [Musical ethnography: Methodology and methods of teaching]. Москва: Советский композитор.

Czekanowska, Anna. 1987. Etnomuzykologia współczesna: Refleksje metodologiczne. [Modern Ethnomusicology: Methodological reflections] Bydgoszcz: Pomorze.

Czekanowska, Anna. 2000. Pathways of Ethnomusicology. Warszawa: Towarzystwo Naukowe Warszawskie.

Dahlig, Piotr. 1993. "Julian Pulikowski i Akcja Zbierania Folkloru Muzycznego w latach 1935-39." [Julian Pulikowski and collection of musical folklore in 1935-39] Muzyka 3-4: 119-156. 
Dahlig, Piotr. 1998. Tradycje muzyczne a ich przemiany: Między kultura ludowa, popularna $i$ elitarna Polski międzywojennej [Musical traditions and their changes: Between folk, popular and elite cultures] Warsaw: Instytut Sztuki Polskiej Akademii Nauk: 517628.

Dahlig, Piotr. 2000a. "The early field recordings in Poland (1904 - 1939) and their relations to the Phonogram-archives in Vienna and Berlin" 100 Years Berlin Phonogramm-archiv: Retrospective, Perspective and Interdisciplinary Approaches of the Sound Archives of the World. Berlin.

Dahlig, Piotr. 2000b. “'Hola matulu moja': Polish folk song, sung by Michał Kulawiak, recorded by Lucjan Kamieński in Poland, January 1930." Music in the Berlin Phonogramm-Archiv 19002000. [Introductory comments to four phonodiscs] CD 1/40: 118122.

[Hoshovs'kyi, Volodymyr] Goshovskii, Vladimir. 1985. Гошовский, Владимир. “Социологический аспект музыкальной этнографии” [Sociological aspect of musical ethnography] Българско музикознание 9/4: 3-19.

Hood, Mantle. 1969. "Ethnomusicology." Harvard Dictionary of Music/ Willi Apel (ed.), Cambridge: Belknap Press of the Harvard University Press.

Iakubiak, Iarema. 1999. Якубяк, Ярема. Аналіз музичних творів (Музичні форми): Підручник [Analysis of musical works (Musical forms): The Textbook]. Тернопіль: СМП “Астон”.

Kolessa, Filiaret. 1938. Колесса, Філярет. Українська усна словесність [Ukrainian oral literature]. Львів: Накладом фонду "Учітеся, брати мої".

Kolessa, Filaret. 1969. Колесса, Філярет (compiler). Мелодіï украйнських народних дум. [Melodies of Ukrainian folk dumas]. Київ: Наукова думка.

Koliński, M. 1930. "Die Musik der Primitivstämme auf Malaka und ihre Beziehungen zur samoanischen Musik". Anthropos 14 (XXV): 585648. Dissert. Humboldt Univ., Berlin.

Koliński, Mieczysław. 1957. "Ethnomusicology, its problems and methods," Ethnomusicology Newsletter 10: 1-7.

Krader, Barbara. 1980. "Ethnomusicology." The new Grove dictionary of music and musicians: In twenty volumes. Stanley Sadie (ed.). London: 6 Grove's Dictionaries. 
Krohn, Ilmari. 1893-1933. Suomen kansan sävelmiä. [Melodies of the people of Finland]. Helsinki, 1893-1933. Vol. 1-3. Kirjapainossa.

Kulakovskii, Lev. 1983. Кулаковский, Лев. “О К.В. Квитке.” [About K.V. Kvitka]. Памяти К. Квитки 1880-1953: Сборник статей Ред.-сост. А. Банин. Москва: 33-36. Советский композитор.

Kunst, Jaap. 1950. Musicologica: A study of the nature of ethno-musicology, its problems, methods and representative personalities. Amsterdam: Koninklijke Vereening Indisch Institut - Mededelling 90.

Kunst, Jaap. 1955. Ehtno-musicology: A study of its nature, its problems, methods and representative personalities. The Hague: M. Nijhoff.

Kunst, Jaap. 1959 (1960, 1969) Ethnomusicology: A study of its nature, its problems, methods and representative personalities. The Hague: M. Nijhoff.

Kvitka, Klyment. 1922. Квітка, Климент. "Українські народні мелодіï." [Ukrainian folk melodies]. Етнографічний збірник Украӥнського наукового товариства в Києві 2. Київ : Слово.

Kvitka, Klyment. 1923a. Квітка, Климент. "Програма вивчення української народної музики" [The program of studying of Ukrainian folk music] Повідомлення музично-етнографічного кабінета ВУАН 2 Київ.

Kvitka, Klyment. 1923b. Квітка, Климент. М. Лисенко як збирач народних пісень. [M. Lysenko as a collector of folk songs]. Київ.

Kvitka, Klyment. 1924. Квітка, Климент. Професіональні народні співиі цे музиканти на Украӥні: Програма для досліду їх діяльності та побуту [Professional folk singers and musicians in Ukraine: the program of research of their work and life]. Київ: Українська академія наук.

Kvitka, Klyment. 1925a. Квітка, Климент. "Вступні уваги до музично-етнографічних студій." [Introductory notes to the musical-ethnographical studies]. Записки Етнографічного товариства 1: 8-27.

Kvitka, Klyment. 1925b. Квітка, Климент. "Песни Крыма. Собраны и записаны певцом-этнографом А.К. Кончевским [...]” [Songs of Crimea. Collected and recorded by the singer-athnographer A.A. Konchevskii...] Записки Історико-філологічного відділу УАН 5: 239-250.

Kvitka, Klyment. 1925c. Квітка, Климент. "Потреби в справі дослідження народної музики на Україні.”[The needs in studying folk music in Ukraine]. Музика 2-3: 67-73, 115-121. 
Kvitka, Klyment. 1926. Квітка, Климент. "Українські пісні про дівчину, що помандрувала з зводителем.” [Ukrainian songs about a girl who wandered with criminals] Етнографічний вісник УАН 2.

Kvitka, Klyment. 1928a. Квітка, Климент. “Ангемітонні примітиви i теорія Сокальського." [Anhemitonic primitives in the theory of Sokal'sky]. Етнографічний вісник УАН 6: 82-83.

Kvitka, Klyment. 1928b. Квітка, Климент. “Максимович і Аляб'єв в історії збирання українських мелодій." [Maksymovych and Aliab'ev in history of collection of Ukrainian melodies]. Первісне громадянство та його пережитки на Україні 1: 119-144. Київ: Державне видавництво України.

Kvitka, Klyment. 1928c. Квітка, Климент. "Порфирій Демуцький." [Porfyrii Demuts'kyi]. Етнографічний вісник УАН 6: XLVII.

Kvitka, Klyment. 1929a. Квітка, Климент. "И.К. Зданович. Белорусские народные песни Гродненской губ., м. Селец." [I.К. Zdanovich. Belarusian folk songs from Grodno guberniia, town Selets]. Труды Государственного Института Музыкальной науки. Сборник работ Этнографической Секиии. Вып. 1-й. Москва. Етнографічний вісник УАН (1929) 8: 234.

Kvitka, Klyment. 1929b. Квітка, Климент. "В справі досліду народньої музики неукраїнських елементів людности УСРР." [to the question of studying of folk music of non-Ukrainian peoples in USRR] Бюлетень Етнографічної комісії Всеукраїнської Академії Наук 11: 3.

Kvitka, Clement. 1930a. "La système anémitonique pentatonique chez les peuples Slaves." Pamiętnik II. Zjazdu słowiańskich geografów $i$ etnografów odbytego $w$ Polsce $w$ roku 1927. Kraków: Komitet Organizacyjny II. Z.S.G.E. 2: 196-200.

Kvitka, Klyment. 1930b. Квітка, Климент. "Кабінет Музичної етнографії Всеукраїнської Академії Наук: Здобутки.” [The office of musical ethnography of All-Ukrainian Academy of Sciences: Achievements]. Побут 6-7: 5-22.

Kvitka, Klyment. 1941. Квітка, Климент. “Об областях распространения некоторых типов белорусских календарных и свадебных песен." [About the regions of spreading of certain types of Belarusian calendar and wedding songs]. Белорусские народные песни / Составитель 3.В. Эвальд. Москва-Ленинград: 123-131.

Kvitka, Klyment. 1956. Квітка, Климент. "Іван Франко як виконавець народних пісень." [Ivan Franko as a performer of folk songs]. 
Творчість Івана Франка Київ: 160-193 АН УРСР Інститут літератури.

Kvitka, Klyment. 1971. 1973. Квітка, Климент. Избранные труды в 2 $\mathrm{mm}$. [Selected works in 2 vol]. Составление и комментарии В.Л. Гошовского; общая ред. П.Г. Богатырева. Москва. Советский композитор.

Kvitka, Klyment. 1977. Квітка, Климент. "Записи народної творчості. Пісні, записані з голосу Лесі Українки.” [Recordings of folk art. The songs recorded from Lesia Ukrainka]. Леся Українка, Зібрання творів у $12 \mathrm{~mm}$. Т. 9 Київ: Наукова думка.

Kvitka, Klyment. 1985, 1986. Квітка, Климент. Вибрані статті. У 2 ч. [Selected articles. In 2 parts] Київ.

Kvitka, Klyment. 2001. Квітка, Климент. Музылкальныий фольклор и музыкальная фольклористика на Кавказе (из рукописного наследия ученого) [Musical folklore and musical folklore studies in Caucasus region]. Ереван.

Kvitka, Klyment and Adolf Chybiński. 1924. "Instrumenty muzyczne ludu polskiego na Podhalu." [Musical instruments of Polish people from Podhalie]. Prace i materjaty antropologiczno-archeologiczne $i$ etnograficzne wydawane staraniem Komisji Antropologicznej Polskiej Akademji Umiejętności w Krakowie 3.

List, Georg. 1979. "Ethnomusicology: A discipline defined." Ethnomusicology 1: 1-4.

Liudkevych, Stanislav. 1921. Людкевич, Станіслав. Загальні основи музики (теорія музики) [General basis of music (Theory of music)]. Коломия: Загальна книгозбірня.

Lotte, D.S. 1961a. Лотте, Д.С. Основы построения научнотехнической терминологии: Вопросы теории и методики [Тһе basics of creating scientific-technical terminology]. Москва: Издательство АН СССР.

Lotte, D.S. 1966b. Лотте, Д.С. Как работать над терминологией: Основы и методы [How to work on terminology: Basics and methods]. Москва: Наука.

Marx, Adolf. 1839. Allgemeine Musiklehre. Leipzig: Breitkopf und Härtel.

Mazel', Lev. 1960. Мазель, Лев. Строение музыкальных произведений [Morphology of musical works]. Москва.

McAllester, David P. 1963. "Ethnomusicology, the field, and the Society," Ethnomusicology 3: 182-186. 
Mel'nyk-Hnatyshyn, O. 1995. Мельник-Гнатишин, О. (compiler). Книгозбірня Філарета Колесси: Каталог [The library of Filaret Kolessa: The catalogue]. Львів № 249.

Merriam, Alan P. 1964. The Anthropology of Music. Evanston: Northwestern University Press.

Merriam, Alan P. 1977. "Definitions of "comparative musicology' and 'ethnomusicology': An historical-theoretical perspective." Ethnomusicology 2: 198-204.

Moroz, М. 1992. Мороз, М. Філарет Колесса (1871-1947): Бібліографічний покажчик прачь $i$ критичної літератури [Filaret Kolessa (1871-1947): The Bibliographic index of works and critical literature]. Львів: Наукове товариство ім. Шевченка.

Myers, Helen. 1992. "Ethnomusicology," Ethnomusicology: An Introduction Helen Myers (ed.), New York: W.W. Norton, 3-19.

Nettl, Bruno. 1958. "Historical aspects of Ethnomusicology." American Anthropologist 60: 518-532.

Nettl, Bruno. 1991. The Dual Nature of Ethnomusicology in North America in "Comparative musicology and anthropology of music". Bruno Nettl and Philip V. Bohlman (eds.). Chicago: University of Chicago Press. 266-274.

Riemann, H. 1889. Katechismus der Kompositionslehre. Leipzig: M. Hesse.

Rozdol's'kyi, Iosyf and Stanislav Liudkevych. 1906, 1908. Роздольський, Йосиф і Станіслав Людкевич. "Галицько-руські народні мелодіï” [Galycian-rusian folk melodies]. Етнографічний збірник НТШ. Т. XXI-XXII. Львів.

Schaeffner, André. 1956. "Ethnologie musicale ou musicologie comparée?" Cercle international d'études ethno-musicologiques: Les Colloques de Wégimont 18.I.1954, Bruxelles: Elsevier.

Schaeffner, André. 1961. "Contribution de l'ethnomusicologie à l'histoire de la musique." International Musicological Society Report of the $8^{\text {th }}$ Congress. Basel: 376-379.

Schramm, Adelaida Reyes. 1979. "Ethnic music, the urban area, and ethnomusicology." Sociologus 29: 1-21.

Simon, Artur. 1978. "Probleme, Methoden und Ziele der Ethnomusikologie." Jahrbuch für Musikalische Volks- und Völkerkunde 9: 8-52.

Sobiescy, Jadwiga i Marian. 1973. Polska muzyka ludowa i jej problemy. [Polish folk music and its problems] L. Bielawski (red.). Kraków: Polskie Wydawnictwo Muzyczne. 
Sposobin, Igor'. 1947. Способин, Игорь. Музыкальна форма. [Musical form]. Москва: Государственное музыкальное издательство.

Stęszewski, Jan. 1992. "Zur Geschichte des Terminus 'Ethnomusicology'." Von der Vielfalt musikalischer Kultur: Festschrift Josefs Kuckertz. R. Schumacher (ed.). Anif/Salzburg: 527-534: U. MüllerSpeiser.

Storozhuk, A. 1998. Сторожук, А. Климент Квітка (людина педагог - вчений) [Klyment Kvitka (a person - pedagogue researcher)]. Київ: Видавництво УАННП “Фенікс".

Tokarev, S.A. 1978. Токарев, С.А. История зарубежной этнографии [History of foreign ethnography]. Москва: Высшая школа.

Ukraïnka, Lesia. 1917/1918. Народні мелодії з голосу Лесі Українки.

Списав Климент Квітка. [Folk melodies as sung by Lesia Ukraïnka. Recorded by Klyment Kvitka]. Київ. Republished in: Українка, Леся. Зібрання творів у 12 mm. (Київ, 1977). - Т. 9: "Записи народної творчості. Пісні, записані 3 голосу Лесі Українки"[Recordings of folk art. Songs as performed by Lesia Ukraïnka].

"Whither ethnomusicology? The scope and aims of ethnomusicology (two panel discussions held in 1958)." Ethnomusicology 2 (1959): 99-105.

Winkelman, Donald M. 1963. "Ethnomusicology at American universities: A curricular survey." Ethnomusicology 7: 113-123.

Wiora, Walter. 1957. "Älter als die Pentatonik." Studia memoriae Belae Bartók sacra. Budapest: 185-208. Aedes Academiae Scientiarum Hungaricae.

Wiora, Walter. 1965. "Ethnomusicology and the history of music." Studia Musicologica 7: 187-193.

Zales'ka, R. And A. Ivanyts'kyi. 1992. Залєська, Р. і А. Іваницький. "Листування Климента Квітки і Філарета Колесси." [Correspondense of Klyment Kvitka and Filaret Kolessa] Записки Наукового товариства імені Т. Шевченка. Т. ССХXIII. Прачі секиії етнографії та фольклористики. Львів: 324-325

Żerańska-Kominek, Sławomira. 1995. Muzyka w kulturze: Wprowadzenie do etnomuzykologii [Music in culture: introduction to ethnomusicology] Warsaw: Wydawnictwo Uniwersytetu Warszawskiego.

Translated by Hanna Chuchvaha and Andrij Hornjatkevyč 